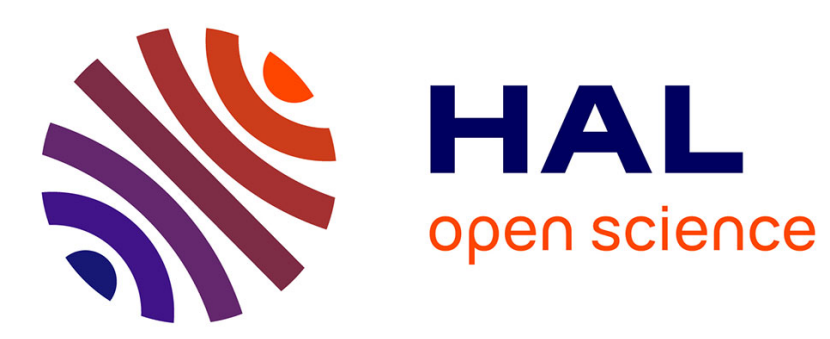

\title{
Addressing the Wicked Problem of Responsible Innovation through Design Thinking
}

\author{
Xavier Pavie, Daphné Carthy
}

\section{To cite this version:}

Xavier Pavie, Daphné Carthy. Addressing the Wicked Problem of Responsible Innovation through Design Thinking. 2014. hal-00921428v2

\author{
HAL Id: hal-00921428 \\ https://essec.hal.science/hal-00921428v2 \\ Preprint submitted on 26 May 2014
}

HAL is a multi-disciplinary open access archive for the deposit and dissemination of scientific research documents, whether they are published or not. The documents may come from teaching and research institutions in France or abroad, or from public or private research centers.
L'archive ouverte pluridisciplinaire HAL, est destinée au dépôt et à la diffusion de documents scientifiques de niveau recherche, publiés ou non, émanant des établissements d'enseignement et de recherche français ou étrangers, des laboratoires publics ou privés. 
Xavier Pavie, Ph.D. ${ }^{1}$, DaphnéCarthy ${ }^{2}$

\begin{abstract}
:
In this paper, we present the results of a study conducted with several major actors from the French financial industry, which aimed at developing a process for developing responsible innovations by deploying a Design Thinking method. We begin by presentingthe context for the study which includes a brief description of our approach for understanding and exploring the issues raised by responsible innovation. This first part also includes a comparative analysis of the characteristics of RI (responsible innovation) and wicked problems in order to establish a potential link between the two concepts. Secondly, the Design Thinking method is introduced as a potentially suitable approach for addressing wicked problems and thus, RI. Finally, the process for developing responsible products and services which was developed throughout the study is presented.
\end{abstract}

Keywords:Responsible Innovation, Design Thinking, Wicked Problem

${ }^{1}$ Director ESSEC-ISIS (Institute for Strategic Innovation\& Services). ESSEC Business School, Av Bernard Hirsch, BP 50105 Cergy.95021 CergyPontoiseCedex - France. pavie@essec.edu

${ }^{2}$ Researcher ESSEC-ISIS (Institute for Strategic Innovation \&Services).ESSEC Business School, Av Bernard Hirsch, BP 50105 Cergy.95021 CergyPontoiseCedex - France. carthy@essec.edu 


\section{Introduction}

A relatively new, yet defining concept of the $21^{\text {st }}$ century, responsible innovation is currently being developed by a multitude of contributors from a wide range of disciplines, from science and technology to philosophy and humanities. So far, the main focus of the RI debate has been geared towards the emergence of new technologies (Blok and Lemmens 2014), which may bring societal risks completely unknown to us, thereby justifying the need for a responsible development (Von Schomberg 2014). Many projects have been launched and sponsored by the European Commission ${ }^{3}$ (notably as part of the ongoing Horizon 2020 programme) over the past few years, aiming to develop a widely accepted definition of the concept in order to guide policy-makers, organisations and all stakeholders affected by these innovations. However, while RI is increasingly considered to be an imperative for organisations and the literature is growing at a remarkable pace, few contributions have addressed the operational integration of the concept.Moreover, some research has hinted at the 'wickedness' of responsible innovation (Blok and Lemmens 2014). Is it therefore, on the one hand, realistic to imagine a society and marketplace where RI guarantees the required balance between responsibility and competitiveness? On another hand, could responsibility potentially become a lever of creativity?

This paper will analyse the similarities between responsible innovation and wicked problems, thereby establishing whether RI can be considered'wicked' in the first place. Secondly, design thinking will be introduced as a tool for addressing wicked problems and, thus potentially, responsible innovation. Finally, we will describe the process for developing responsible innovation which was constructed with the design thinking method during the project. It is important to note that the process for developing responsible products and services is only one part of the full RI process required for integrating the RI strategy across the organisation as a whole (Pavie\&Carthy 2013). Indeed, the full process is made up of the following five stages: 1. comply with the law; 2. anticipate future legal requirements; 3. treat the value chain as an ecosystem; 4. innovate responsibly; 5. lead the change.

\footnotetext{
${ }^{3}$ GREAT (Governance for REsponsibleinnovATion) ; KARIM (Knowledge Acceleration Responsible Innovation Meta-network) ; Responsibility: Global Model and Observatory for International Responsible Research and Innovation Coordination; FaRInn (Facilitating Responsible Innovation in SEE countries), to name but a few.
} 
The study presented in this paper resulted from a project initiated in 2011 in response to a need expressed by several French financial institutions in search of an operational process for integrating RI. The aim of the project was to develop an effective tool to assist organisations in the development of responsible products and services. This project was unique in the sense that it led to the production of a management method for the responsible innovation process of banks and insurance companies. The methodology was largely based on a design thinking approach and involved the creation of a "co-opetitive" working group made up of actors from a sector which is generally known for its extreme competitiveness.

\section{Context}

The emergence of a concept

From the first appearance of sustainability as an element of innovation in the literature of the mid-1990s (Fussler and James 1996; Godin 2008) - which followed the introduction of the Sustainable Development theory in the late 1980s (Brundtland 1987) - to the ongoing development of the sustainable innovation concept, it is clear that innovation has become inherently suspect.This in turn has given rise to the concept of responsible innovation which we wish to define as "an iterative development process which combines a step-by-step impact analysis of a project with the imperatives of creativity stimulation throughout development phases. Social, economic and environmental performance impacts are monitored throughout the entire lifecycle and corrective actions are anticipated accordingly through re-integration into previous development phases" (Scholten, Pavie and Carthy, 2014).

The emerging urgency for a consideration of the practical applicability (Blok and Lemmens 2014) of the concept of responsible innovation was reflected in the study presented in this paper. Indeed, the participating French institutions expressed their need for an operational process of integration of responsible innovation which would fulfill their responsibility criteria and foster the level of creativity needed to spur innovation. This highlights a current gap in the RI literature concerning a process for implementing an RI strategy across an organisation.

As such, we believe that it is important to dissociate responsible innovation from the concept of 'responsible research and innovation' (or RRI, a central theme in the context of the current Horizon 2020 European programme). Indeed, the latter's 
widely used definition describes " $a$ transparent, interactive process by which societal actors and innovators become mutually responsive to each other with a view on the (ethical) acceptability, sustainability and societal desirability of the innovation process and its marketable products (in order to allow a proper embedding of scientific and technological advances in our society)" (Von Schomberg 2011). However, applying responsibility to a research context will raise issues different to the ones faced in the context of innovation. In fact, while research impetus is generally characterized by its epistemic significance, the goal of innovation is to create value for the organization in a competitive context, with the ultimate objective of releasing and commercializing a finished product. Thus, the fundamental difference in the end purpose of each concept defines the separation between responsible innovation - as an operational process - and RRI as a theoretical concept which is yet to be accurately adapted for organizations in need of practical tools aimed at supporting innovators in their day-to-day activities.

Three axes contribute to a better identification and understanding of the issues raised by responsible innovation (Pavie 2012; Pavie et al. 2014). Firstly, the questioning of the solutions to develop in response to individual needs suggests adopting a slightly more philosophical approach to business in general and more precisely to the answer of certain consumer needs. Secondly, the monitoring of the direct impacts of innovation on the consumer requires the effective management of the innovation throughout the entire lifecycle to ensure that any negative impacts on the consumer are identified and corrective action is taken accordingly. Thirdly, the consideration of the indirect impacts of the innovation on the surrounding social, economic and environmental factors aims at guaranteeing that the ecosystem as a whole is taken into account in the impact analysis.This is carried out throughout the development of the project and continues once it has been launched on the market. In some instances, responsible innovation may be considered an evolution or modernisation of the sustainable development theory, since it incorporates the issues emerging within the socio-economic and political landscape of the $21^{\text {st }}$ century. Indeed, while the Brundtland report was suited to the society at the time it was issued, it does not include a specification of the final objectives of innovations nor the strategic aspects and consequences of organisations' activities. Since innovation plays such a critical role in shaping society at a social, economic and environmental level, these are critical factors which can no longer be overlooked (Pavie 2012). 


\section{Responsible innovation, a new wicked problem?}

The theories and issues linked to the sustainable development concept are generally associated with the characteristics attributed to wicked problems (Norton 2005; Raffaelle et al. 2010 ;Brundiers and Wiek 2010). First introduced by Rittel and Weber in 1973, wicked problems were used to describe untamed problemswhich are difficult to pin down, highly complex and not amenable for concrete solutions. They represent complex systems in which cause and effect relations are uncertain or unknown. Rittel and Webber developed a set of characteristics to define the complex concept more accurately; these include the fact that every wicked problem can be considered to be a symptom of another problem; there is no immediate and no ultimate test of a solution to a wicked problem, however every potential solution to a wicked problem is also a 'one-shot' operation, as there is no opportunity to learn by trial and error: every attempt counts significantly and the existence of a discrepancy representing a wicked problem can be explained in numerous ways. Part of the reason for the complexity of wicked problems is linked to the multitude of stakeholders with diverging motives who are involved in solving these problems. Due to their differing backgrounds, perspectives and motivations, their individual interpretation of the problem varies greatly (Kreuter et al. 2004).

The same complexity applies to responsible innovation since the implementation of an RI strategy in any sector and organisation is carried out through a process involving a multitude of actors, each with their own specificities and characteristics who will wish to address certain issues very differently from the way employed by their collaborators or colleagues (Blok \&Lemmens 2014). It is important to highlight the competitive landscape surrounding innovation which adds to the 'wicked' nature of RI. It therefore follows that responsible innovationcan be described and treated as a wicked problem since scratching the surface to solve an issue inevitably reveals new arising issues to be addressed.

Responsible innovation: a wicked problem in an organisational context

As described earlier, multiple stakeholders are involved in a responsible innovation process. Furthermore, the wicked problem of responsible innovation is defined by its high level of uncertainty with regards to the outcome (Batie 2008) or in the case of innovation: the final product or service launched on the market. This uncertainty also concerns the potential causes and effects underlying the problem linked to the innovation project, whether throughout the development phases of the latter or 
even at the post-launch phase.As mentioned earlier, the wicked problem of responsible innovation is set in a highly competitive context, subject to intense market pressure, thereby adding to its complexity. Since the definition of a wicked problem tends to change over time as potential solutions are being formulated, tested and adapted, it appears that they are never solved (Conklin 2006), but rather become better or worse (Rittel and Webber 1973). However, how can responsible innovation - a necessity for organisations (Pavie 2012) -translate into an operational process aiming at combining responsibility and performance?

\section{Methodology: a new approach for solving the wicked problem of responsible innovation through design thinking}

\section{Definition, general scope and benefits of design thinking}

Design thinking is a strategy based on user-centric design methods and principles which first appeared in the 80s and was developed and made popular by IDEO's David Kelley and Tim Brown over the late 90s (Kelley \& Littman 2001). In fact, the widely used definition of design thinking was suggested by IDEO's CEO: " $a$ discipline that uses the designer's sensibility and methods to match people's needs with what is technologically feasible and what a viable business strategy can concert into customer value and market opportunity" (Brown 2008).

This creative discipline is incorporated into the innovation process in order to develop specific solutions to address complex issues. Design thinking differs from industrial design - which typically tends to apply to the manufacturing sector through several intrinsic characteristics including its vision and approach to innovation, its experiential, iterative and multidisciplinary method as well as the wide range of sector within which it can be applied. The current revival of interest for design thinking is justified by its effective method for creating concrete solutions to address organisations' new needs and requirements in terms of innovation.

Design thinking's pioneering approach appears to be particularly effective and relevant in terms of solving wicked problems, especially in terms of addressing the operational integration of responsible innovation.Indeed, design thinking represents a unique combination of scientific and technical rigour; an understanding of the needs of human beings and society in general; a clear consideration for the 
economic imperatives of an organisation and also provides a basis for monitoring the environmental impact of a project.

Today, design thinking has answered the wishes for the progress and development of design which were expressed by Victor Papanek in the 70s. Indeed, at that time, he already hoped for a discipline of design which would be an "innovative, highly creative, cross-disciplinary tool responsive to the needs of men. It must be more research-oriented and we must stop defiling the earth itself with poorly-designed objects and structures” (Papanek, 1971).

Design thinking has many benefits, including its ability to articulate itself around and adapt to the organisation's innovation process. There are five main objectives to this method, including the opening up of the innovation process to include customers, stakeholders and experts capable of providing guidance with regards to potential impacts; the improved understanding of customer needs and expectations, by involving these throughout the process; the full use and management of new distribution channels through the cross-disciplinary work; the reduction of risks posed by innovations by making an impact monitoring system central to the innovation process and the redefined role of organizations as actors actively shaping the future of society.

\section{Explanation of design thinking method for developing responsible innovations}

Design thinking has been proved in the past to be aneffective tool for solving “wicked problems” (Zimmerman et al. 2010; Nelson 2008; Coyne 2005), for which, as mentioned earlier, there is no simple or straight forward method of solution (Rittel and Webber 1973). The same definition could be used to describe responsible innovation as it raises more questions in the process of trying to provide answers to the already existing issues.

Hence, through a multidisciplinary approach, design thinking tackles wicked problems through a three-pronged approach: desirability (human needs); viability (business needs) and feasibility (technical needs) (Brown 2008). The first point is concerned with putting the users and stakeholders at the centre of development, by assessing whether the solution is genuinely useful and therefore shows empathy towards users by optimising ease of use. The second point addresses the business requirements for developing a specific solution, in terms of adequate resources and know-how as well as previsions on profitability and ROI. The third point deals 
with the technical needs of the solution, in other words: can we implement the solution rapidly? Is it easy to maintain? Is it consistent with regards to our current situation?

Traditionally associated with the downstream innovation process of products and services and considered to simply provide an attractive packaging for the client thereby providing limited results in terms of value creation, design thinking has now become an integral part of the innovation process. Indeed, it plays a strategic role in value creation through the creation of ideas that better answer the expectations and needs of consumers.

Design thinking methods vary from one organisation to another and can be adapted accordingly to suit specific sectors. The method used in this project was developed by AltranPr[i]me and is made up of five stages, as illustrated in Figure 1.

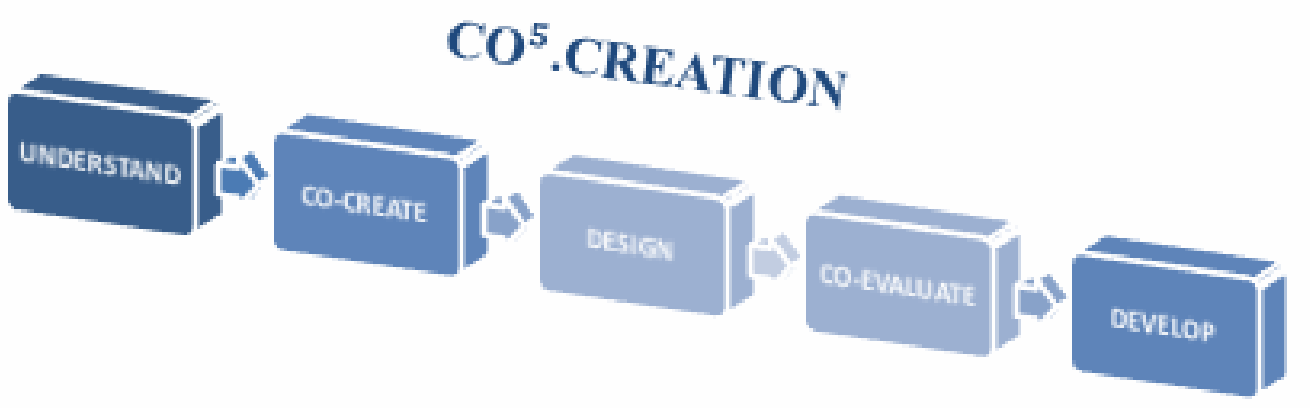

\section{Figure 1. C05. Création (Altran $\operatorname{Pr}[i] m e ~ 2014)$}

The method used consisted of the following elements:

1) The creation of a multidisciplinary group in order to generate a global vision of the problem at hand, which involves the integration of responsibility into the innovation process of organisations (focusing on the financial sector, while bearing in mind the need to keep the process adaptable and applicable to other sectors). As such, the working group consisted of philosophers, academics, anthropologists, designers, banking and insurance sector specialists as well as end users.

2) The separation of the theoretical and practical dimensions of responsible innovation to ensure that each part was treated accordingly and simultaneously. As such, the theoretical approach consisted in an analysis 
of existing research surveys and a literature review to conduct a debate surrounding the topic of innovation and philosophy, while the practical approach, in parallel, consisted in conducting a series of ethnological interviews with regular bank and insurance customers and industry specialists, to assess their views on financial institutions, the industry as a whole and the role of innovation and responsibility within that sector.

3) Following the background work and on the basis of resulting syntheses, four workshops were organised to process, exchange and debate surrounding the information and with regards to the issues raised:

- Workshop 1 was dedicated to the exact formulation and wording of the issues being treated as well as the definition of the parameter to which the responsible innovation method would be applicable. This facilitated the development of the first draft for the responsible innovation process.

- Workshop 2 was dedicated to the research of new service concepts which would be deemed responsible. This workshop was essentially centred on the final user and resulted in the development of twelve different concepts.

- Workshop 3 was dedicated to the analysis of the concepts developed in the previous workshop by confronting them to the first draft of the responsible innovation process derived from Workshop 1. This session allowed both the refinement of the process (creation of a responsible innovation process including the evaluation of impacts according to social, economic and environmental criteria) and the further development of the service concepts. Three concepts were then selected as those that were considered most likely to be developed into real responsible services.

- Workshop 4 consisted in testing the three service concepts by evaluating them in terms of responsible innovation, through the responsible innovation process and its impact analysis based on the social, economic and environmental criteria. This final workshop also enabled the finalisation of the responsible innovation process, as potential practical drawbacks were identified throughout the analysis of the service concepts.

\section{Design Thinking's contribution to an integration of responsible innovation}

The main objective set at the beginning of the project was to design a method capable of supporting the development of responsible innovations in the banking and insurance sector while taking into account social, economic and environmental 
impacts linked to the new product or service. The design thinking method aimed to provide a process for assessing an innovation in the light of the three axes of responsible innovation and the principle of responsibility, as well as to identify potential innovative and responsible products and services. The design thinking method facilitated the merging of the necessary theoretical and practical approaches to address responsible innovation as a wicked problem.

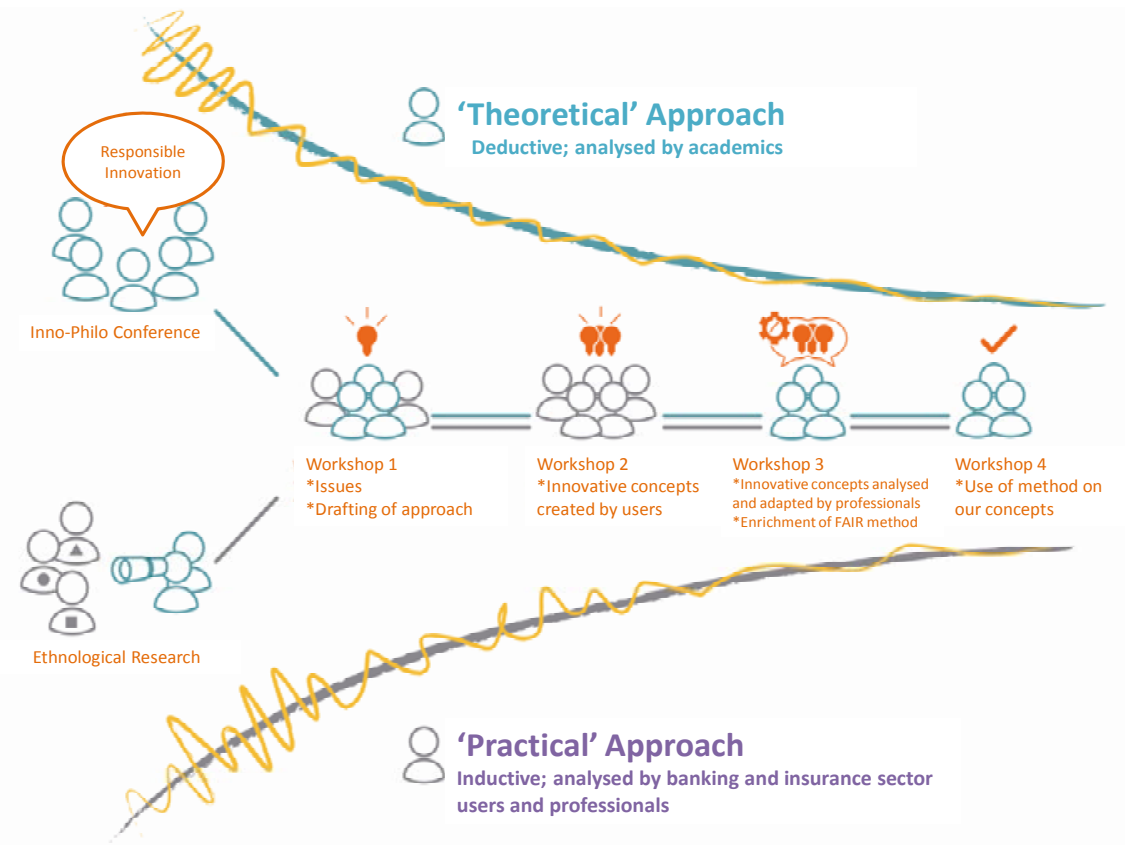

Figure 2. Illustration of the design thinking method for developing

\section{a responsible innovation process}

Figure 2 illustrates the simultaneous approaches of the theoretical and practical elements of the method. On the one hand, academics addressed the issue of defining responsible innovation and how the responsibility of an innovation might be measured in order to feed that information into the analysis of the innovation process based on the three axes of responsible innovation. On the other hand, anthropologists conducted surveys with both financial sector professionals and customers to examine their interpretation of responsibility and how an innovation could become responsible from their perspective. The results of both approaches were then analysed conjointly in order to create a process for the assessment of an innovation in light of the concept of responsibility and the identification of potential innovative and responsible products and services. 


\section{Results: a process for developing responsible products and services}

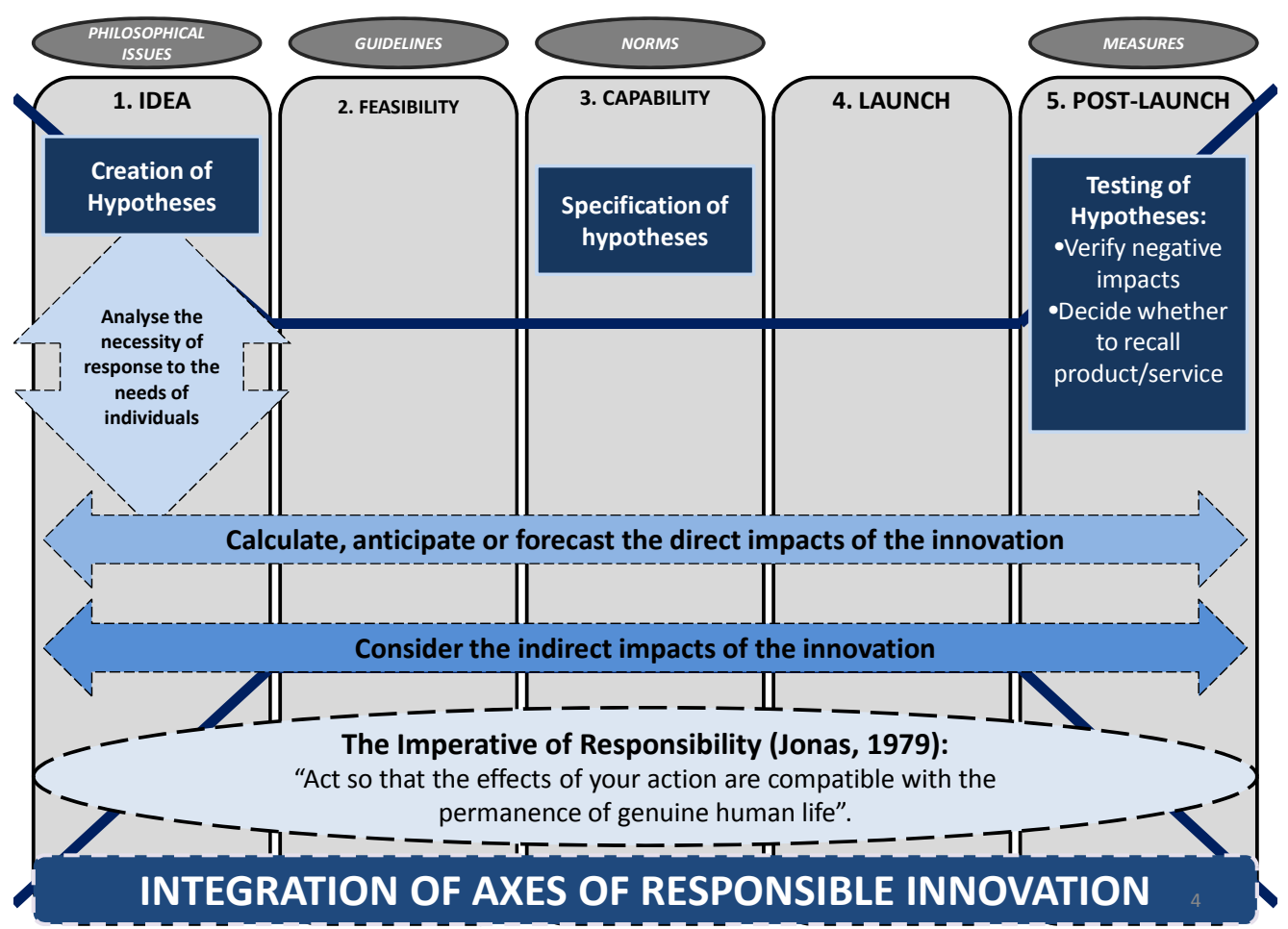

Figure 3. An integration of the axes of responsible innovation

As illustrated in Figure 3, a classic five-step innovation process was used as the basis for developing one which would fully integrate the principle of responsibility at the heart of the responsible innovation theory. The most relevant social, economic and environmental factor criteria were selected to be placed by all participants of the study at different phases of the innovation process in order to monitor impacts. Thus, each stage of the process was attributed a sub-title to further define the purpose of that particular phase. As such, the idea phase was labeled as the stage where 'philosophical issues' should be addressed in answering the relevant social, economic and environmental criteria. In addition, the first axis of responsible innovation which questions whether to answer a newly discovered consumer need evidently intervenes at this initial stage of the process. In order to keep track of potential risk factors related to the project which will only be measurable once it is launched, these should be formulated into hypotheses to be tested post-launch. The feasibility phase was labeled as the stage where the analysis of potential social, economic and environmental impacts should serve as 'guidelines' for the further development of the project in the right direction. The capability stage was labeled in order to monitor impacts related to this stage and to be aware of 'norms' (eg. legal, environmental) which could impact the innovation 
project. Furthermore, this phase should include a specification of the risk hypotheses as the project is becoming more defined and additional hypotheses may be added while some may no longer be relevant. The aim of the process is to ensure that the launch of the innovation is successful, while guaranteeing the control of the full lifecycle with regards to potential impacts which are therefore analysed ('measures') in the post-launch phase. The results obtained from testing the risk hypotheses should support management in their decision to recall or not a product if negative impacts are deemed too harmful with regards to social, economic, environmental factors or indeed on the consumers themselves. In such a case, the responsible innovation process should ensure a swift withdrawal of the innovation from the market in order to reinsert it into a previous development phase for amendment.

The design thinking method helps to combine the need for creativity with the monitoring of impacts; as such the need for responsibility is used as a lever for developing better innovations which are at the service of citizens and not the other way around.

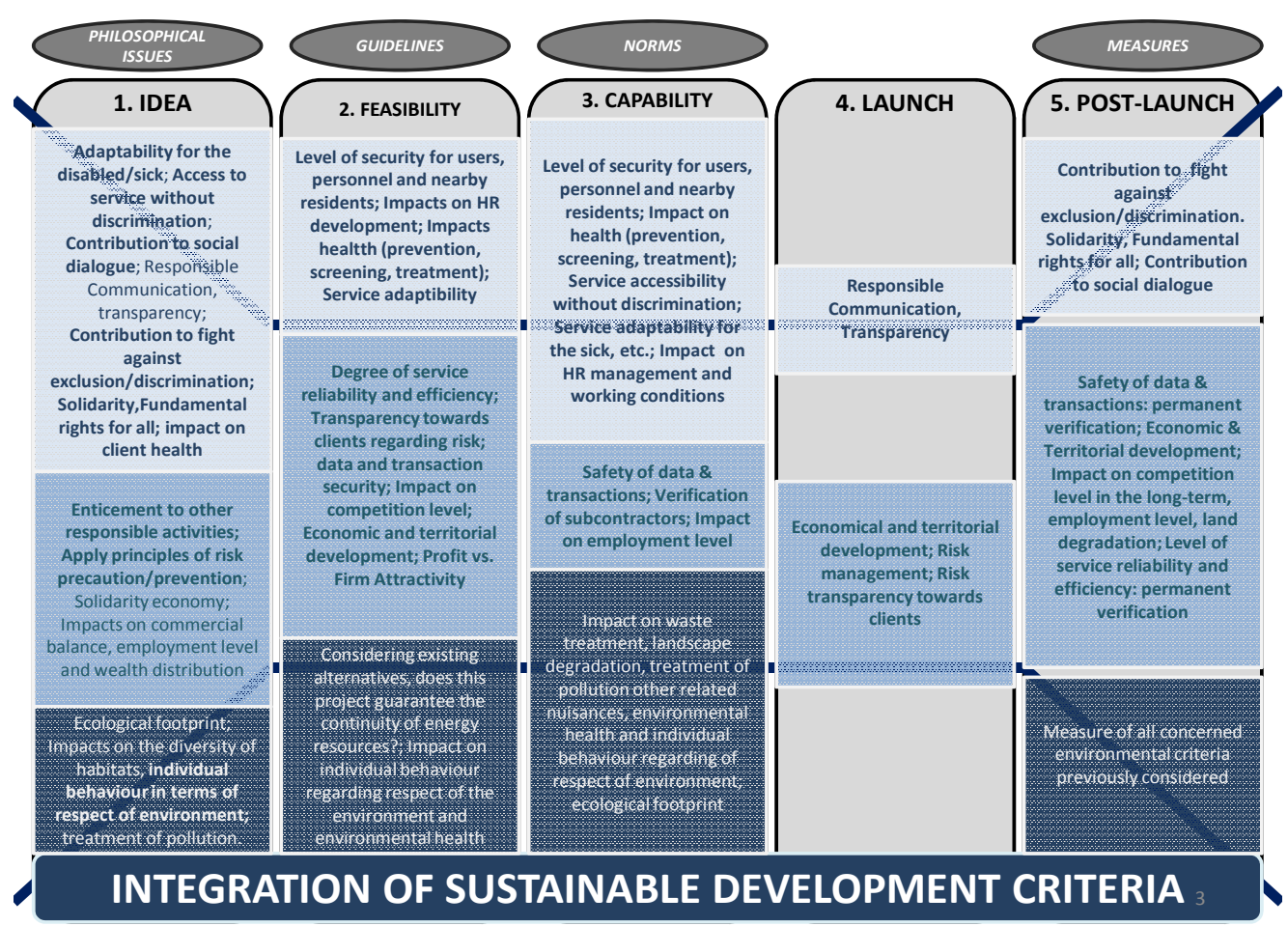

Figure 4. An integration of Brundtland's sustainability criteria

One of the main objectives of the responsible innovation process is to guarantee that the creativity of the multidisciplinary team is unleashed fully, thereby ensuringthat the need for responsibility does not stifle the process for generating 
ideas. In that regard, design thinking can gear the brainstorming session and the reflection of individuals toward answering a particular consumer need, while considering the responsibility criteria.

Social, economic and environmental criteria should be adapted depending on the project; this once again highlights the importance of a multidisciplinary team to ensure varying perspectives can contribute to the analysis. For instance, a social criterion could address the design of the product and question whether it would encourage other responsible activities, while an economic criterion could question the impact of the potential innovation on the level of employment and an environmental criterion could raise the issue of the project's ecological footprint, both throughout development phases and once the final product has been launched. Various questions arise at different steps of the process, as the type of information required will vary depending on the progress made by the project. Figure 5 illustrates the process for developing responsible innovations through design thinking. It also positions it as a sub-process occurring at the fourth stage ('Innovate responsibly through Design Thinking') of the full organisation's strategic RI integration process.

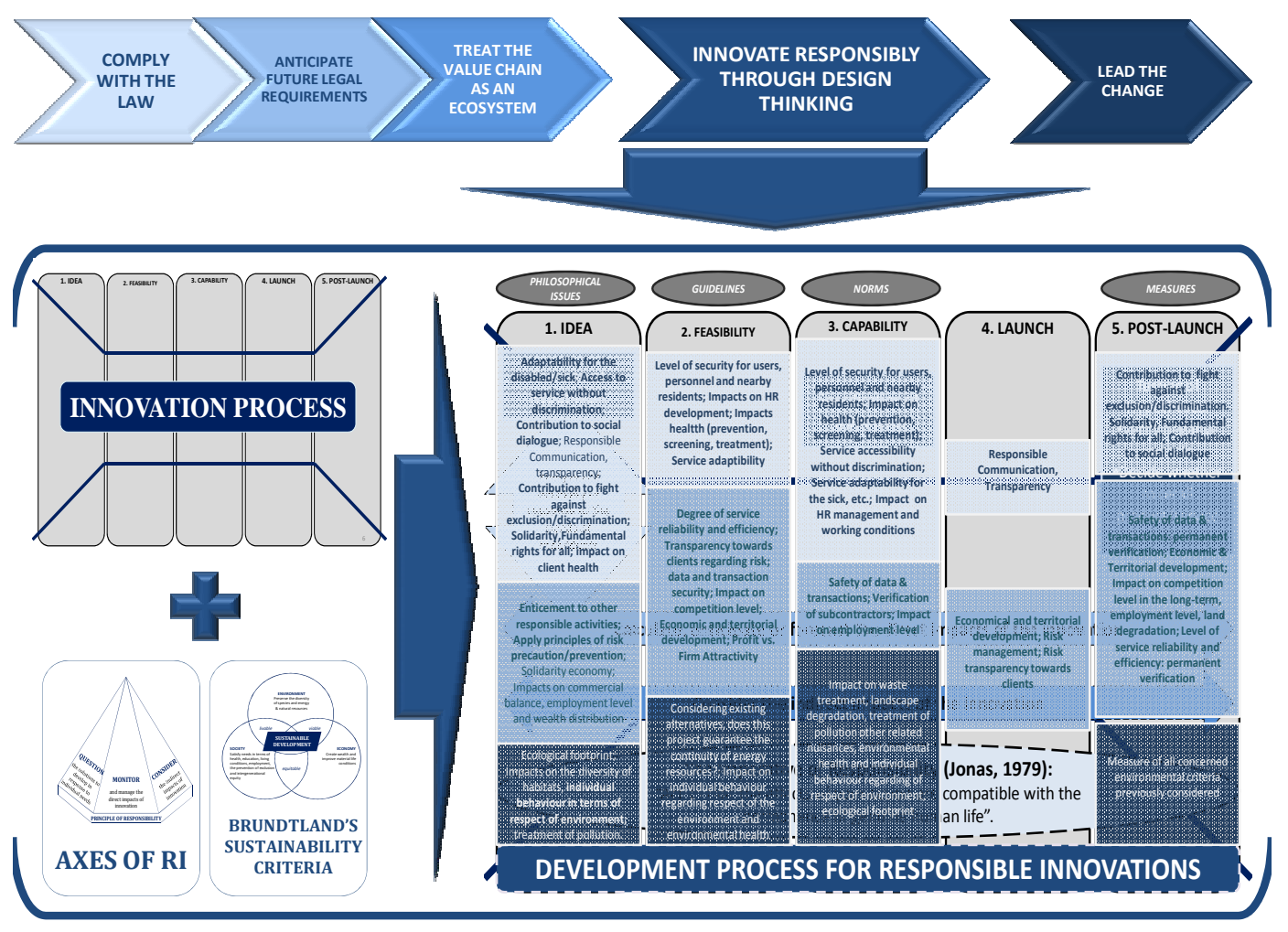

Figure 5. Developing responsible products and servicesthrough design

\section{thinking}




\section{Conclusion}

Issues linked to sustainable development are generally referred to as wicked problems. This is partly due to the fact that there generally is no black or white answer to such issues since multiple stakeholders are involved, all with their own diverging motives and perspectives. Responsible innovation is evidently linked to questions surrounding sustainability as it takes into account the potential impacts of an innovation whether on the consumers themselves and/or on a social, economic and environmental level. Indeed, it requires a process which monitors and manages impacts throughout the innovation's lifecycle as a whole. At the same time, how can managers ensure that the need for responsibility does not become a major constraint for innovation activities? How can they continue to stimulate the creativity needed in their team to spur innovation, while at the same time keeping control over impacts? Although research surrounding the RI concept is growing at a remarkable rate, organisations are still lacking a concrete process for implementing a strategy to ensure responsibility and performance objectives are met.

Design thinking has been proven an effective method in the past for addressing wicked problems. Indeed, its multidisciplinary approach allows a broad overview of the issue at hand from various perspectives. The designer then gears the reflection of the group towards addressing the problem. As such, the varying perspectives of all stakeholders were taken into account in the design of the RI process. Developing marketable and responsible products and services is a wicked problem in itself which benefits greatly from a design thinking approach, as demonstrated in this project.

The RI methodology developed throughout the project encapsulates several advantages for the organisation. On the one hand, it is designed to be used complementarily to the organisation's existing or 'classic' innovation process. This ensures that the entire lifecycle of the innovation is taken into account. On the other hand, despite having been developed in the context of the finance sector, the RI process is perfectly adaptable to other sectors and organisational structures. 


\section{Bibliography}

Batie, S. S. (2008). 'Wicked Problems and Applied Economics'. American Journal of Agricultural Economics. 90(5): 1176-1191.

Beck, U. (1986).Risikogesellschaft. Frankfurt am Main: SuhrkampVerlag.

Blok, V. and Lemmens, P. (2014).'The emerging concept of responsible innovation. Three reasons why it is questionable and calls for a radical transformation of the concept of innovation'. In: Responsible Innovation: Issues in conceptualization, Governance and implementation (volume 2),Koops, Van den Hoven, Romijn, Swierstra, Oosterlaken (ed.) (Springer 2014 forthcoming).

Brown, T. (2008). 'Design Thinking', Harvard Business Review, June, 8492.

Brundiers, K. \&Wiek, A. (2010).Educating students in real-world sustainability research: Vision and implementation.Innovative Higher Education, 36(2), 107-124. 
Callon, M. and Lacoste, A. (2011). 'Debating Responsible Innovation', Observatory for Responsible Innovation, 1(1): 5-18.

Carson, R. (1962). Silent Spring.Boston:Houghton Mifflin Harcourt.

Conklin, J. E. (2006). Dialog Mapping: Building Shared Understanding of Wicked Problems. Napa, CA: CogNexus Institute.

Covin, J.G. and Slevin, D. (1991). 'A conceptual model of entrepreneurship as firm behaviour', Entrepreneurship: Theory and Practice, 16(1): 7-25.

Drucker, P. (1973). Management: Tasks, responsibilities and practices. New York: Harper \& Row.

Eccles, R.G. and Serafeim, G. (2013). 'The performance frontier: innovating for a sustainable strategy', Harvard Business Review, May Issue, 50-60.

Engel, L. (1997). Réguler les comportements', in T. Ferenczi (eds.), De quoi sommes-nous responsables ?, (Editions Le Monde), pp. 11-36: 80-89.

Ewald, F. (1996). Histoire de l'Etat-Providence. Folio.

Gadioux, S.E. (2010). ‘Qu'est-ce qu'une banque responsable? Repères théoriques, pratiques et perspectives', Management Prospective Ed. Management \&Avenir, 8(38): 33-51.

Gadioux, S.E. (2010). 'Les relations entre la performance sociétale et la performance financière des organisations : une étude empirique comparée des banques européennes et non européennes', Cahier de recherche PRISMSorbonne. CR 10-09.

Gloukoviezoff, G. (2004). 'The “Caissed'Epargne” and Households' Financial Exclusion. Which Actions Should Be Taken and What Are the Prospects?'. Paper presented to the Access to Finance Conference, Brussels, 28 to 29 October. Brussels: World Savings Bank Institute - The World Bank.

Gloukoviezoff, G. (2006). 'From Financial Exclusion to Overindebtedness: The Paradox of Difficulties for People on Low Incomes?' In Aderloni, L., 
Braga, M.D. and Carluccio, E. (eds.). New Frontiers in Banking Services: Emerging Needs and Tailored Products for Untapped Markets. Berlin: Springer Verlag.

Coyne, R. (2005). 'Wicked problems revisited’. Design Studies. 26(1):5-17.

Godin, B. (2008). 'Innovation: The History of a Category'. Project on the Intellectual History of Innovation - Working Paper 1.

Han, J.K., Kim, N. and Srivastava, R.K. (1998). Market orientation and organizational performance: Is innovation a missing link? Journal of Marketing, 62: 30-45.

Hurley, R. and Hult, G.T.M. (1998). Innovation, market orientation, and organizational learning: an integration and empirical examination. Journal of Marketing, 62: 42-54.

Ireland, R.D., Hitt, M.A. and Vadyanath, D. (2002).'Alliance management as a source of competitive advantage'.Journal of Management 28(3): 413446.

Jonas, H. (1979). Das PrinzipVerantwortung: VersucheinerEthikfür die technologischeZivilisation. Frankfurt am Main: Insel-Verlag.

Kelley, T. and Littman, J. (2001).The art of innovation: lessons in creativity from IDEO, America's leading design firm. New York: Currency/Doubleday.

Knox, S. (2002). 'The Boardroom Agenda: Developing the Innovative Organisation’, Corporate Governance, 2(1): 27-36.

Latour, B. (1987). Science in Action.How to Follow Scientists and Engineers through Society. Cambridge, MS: Harvard University Press.

Lumpkin, G.T. and Dess, G.G. (1996).'Clarifying the entrepreneurial orientation construct and linking it to performance', Academy of Management Review, 21: 135-172. 
Merton, R.C. (1995). 'Financial Innovation and the Management and Regulation of Financial Institutions', Journal of Banking and Finance, 19 (January).

Moore, G.A. (1991). Crossing the Chasm.New York: HarperCollins Publishers.

Mueller, R. M. And Thoring, K. (2012). 'Design Thinking vs. Lean Startup: A comparison of two user-driven innovation strategies', 2012 International Design Management Research Conference.

Nelson, H. G. (1994). 'The Necessity of Being 'Un-Disciplined' and 'Out of Control’: Design Action and Systems Thinking'. Performance Improvement Quarterly.7(3):3-129.

Norton, B. G. (2005). Sustainability: A philosophy of adaptive ecosystem management. Chicago, IL: University of Chicago Press.

Papanek, V. (1971).Design for the Real World: Human Ecology and Social Change. Chicago: Academy Chicago Publishers.

Pastré, O. and Jeffers, E. (2006). 'The Economics of Banking: A Necessary Updating of Concepts', $55^{\text {th }}$ Congress of the Association Française de Science Economique, Paris.

Pavie, X. (2012). Innovation responsable. Stratégie et levier de croissance pour les organisations. Paris :Eyrolles.

Pavie, X. (2012).'The importance of responsible-innovation and the necessity of innovation-care’, ESSEC Working Paper, N¹203.

Pavie, X. (2013). 'Le principe d'innovation responsable, principe de l’innovation bancaire?', Revue Banque, Nº762.

Pavie, X. and Carthy, D. (2013). 'Responsible innovation in practice: how to implement responsibility across an organisation', Cahier Innovation \& Society, $\mathrm{N}^{\circ} 33$. 
Pavie, X., Scholten, V. and Carthy, D. (2014).Responsible Innovation: From Concept to Practice. Singapore: World Scientific Publishing Company.

Power, M. (2007). Organized Uncertainty: Designing a World of Risk Management. Oxford: Oxford University Press.

Raffaelle, R., Robison, W., \&Selinger, E. (2010).5 Questions: Sustainability ethics. USA: Automatic/VIP Press.

Regan, S. and Paxton, W. (2003).Beyond Bank Accounts: Full Financial Inclusion. London: Institute for Public Policy Research.

Rittel, H. W. J. and Weber, M. M. (1973).Dilemmas in a general theory of planning.Policy Sciences, (4), 155-169.

Schumpeter, J.A. (1912). Economic Doctrine and Method.New York: Oxford University Press, 1954, translated from the German, 1912.

Schumpeter, J.A. (1939). Business Cycles: A Theoretical, Historical, and Statistical Analysis of the Capitalist Process, New York: McGraw-Hill.

Shevlin, R., Fishman, J., Bézard, J.-M., Vandenbulcke, M. and Auché, J. (2009). 'Comment (r)établir la confiance du consommateur dans les banques?’, Plénitudes Prospective \& Management et Aite Group LLC, Avril.

Srinivasan, S., Pauwels, K., Silva-Risso, J. and Hanssens, D.M. (2009). Product innovations, advertising and stock returns. Journal of Marketing, 73(1): 24-43.

Von Schomberg, R. (2014), From 'Responsible Development of Technologies' to Responsible Innovation. Available at: https://app.box.com/s/2d2hozrpjvf6fg5toxln Adapted from J. Britt Holbrook and Carl Mitcham. Ethics, Science, Technology and Engineering: An International Resource (ESTE2), 2E. (C) 2015 Gale, a part of Cengage Learning, Inc. Reproduced by permission.http://www.cengage.com/permissions 
Von Schomberg, R. (2011), 'Prospects for technology assessment in a framework of responsible research and innovation', in: Technikfolgenabschätzenlehren:

BildungspotenzialetransdisziplinärerMethode, 39-61, Wiesbaden: Springer VS.

Weber, M. (1904, 1905), 'Die ProtestantischeEthik und der 'Geist' des Kapitalismus', ArchivfürSozialwissenschaft und Sozialpolitik, 21: 1-110.

Weerawardena, J., O’Cass, A. and Julian, C. (2006). Does industry matter? Examining the role of industry structure and organizational learning in innovation and brand performance.Journal of Business Research, 59(1): 3745.

Zimmerman, J., Stolterman, E. And Forlizzi, J. (2010).'An analysis and critique of Research through Design: towards a formalization of a research approach'.Proceedings of the $8^{\text {th }}$ ACM Conference on Designing Interactive Systems.310-319. 